\title{
Problematic Issuance of Land Rights Certificate $^{*}$
}

\author{
Moh. Ali Wafa \\ FSH UIN Syarif Hidayatullah Jakarta \\ Jl. Ir. Juanda No. 95 Ciputat South Tangerang
}

DOI: $10.15408 /$ ich.v5i2.7089

\begin{abstract}
:
Many people who have not registered ow nership rights so that they have no protection and legal certainty due to several factors: First, a factor of land ownership history. Second, community psychology Third, weakness of land registration rules. Fourth, executor implementation, intervention Duties on Land and Building Transfer (BPHTB) legislation and other fees. Fifth, the mechanism of registration of land is too expensive for the community both procedure and registration fee. The Solution and effort to minimize the occurrence of land disputes society are: first, by preventing the land dispute case is not repeated. Second, the government immediately socialize what and how the issuance of land certificates and the purpose of certificates. Third, If there is a dispute in the court that the object is not certified land, the court notifies the urban village and local National Land Agency (BPN) to block the transaction or the transition of the land immediately. Fourth, each transaction or transition of land with proof of ow nership in the form of girik, the witness in the transaction should be the Village Head and the BPN officer, and fifth, it is better if there is land dispute in the court, at least one judge from land law expert, such as nonacademic judges (academics).
\end{abstract}

Keyword: Ownership Right, Registration, Certificate.

\footnotetext{
* Received: June 24, 2017, Revised: July 22, 2017, Accepted: Agustus 23, 2017.
} 


\title{
Moh. Ali Wafa
}

\section{Problematika Penerbitan Sertifikat Hak Atas Tanah}

\begin{abstract}
Abstrak:
Masyarakat banyak yang belum mendaftarkan hak kepemilikan berakibat tidak mendapatkan perlindungan dan kepastian hukum, karena beberapa faktor yaitu: Pertama Faktor sejarah kepemikan tanah, kedua, psikologi masyarakat, ketiga, kelemahan aturan pendaftaran tanah, keempat, pelaksana dan pelaksanaan, dan, kelima intervensi undang-undang BРНTB dan biaya lain. Kelima, disebabkan oleh mekanisme pendaftaran tanah terlalu berat bagi masyarakat baik prosedur maupun biaya pendaftarannya. Adapun Solusi dan upaya untuk meminimalisir terjadinya sengketa tanah di tengah-tengah masyarakat adalah pertama, dengan cara mencegah agar kasus sengketa tanah tidak terulang. Kedua, agar pemerintah segera mensosialisasikan apa dan bagaimana pennerbitan sertifikat tanah serta tujuan dilakukan penerbitan serifikat. Ketiga, Jika terjadi sengketa di pengadilan yang objeknya tanah belum bersertifikat, secepatnya pengadilan memberitahukan pihak kelurahan dan BPN setempat untuk memblokir transaksi atau peralihan tanah tersebut. Kempat, untuk setiap transaksi atau peralihan tanah dengan bukti kepemilikan berupa girik, sebaiknya saksi dalam transaksinya adalah Lurah dan pegawai BPN, dan Kelima, adalah lebih baik jika terjadi sengketa pertanahan di pengadilan, paling tidak satu hakim anggota majelis adalah berasal dari pakar hukum tanah, seperti hakim nonkarier (akademisi) agar pertimbangan putusannya lebih berbobot.
\end{abstract}

Kata Kunci: Hak Milik, Pendaftaran, Sertifikat

How to cite (turabian):

Wafa, Moh. "Problematic Issuance of Land Rights Certificate" JURNAL CITA HUKUM [Online], Volume 5 Number 2 (December 2017). 


\section{Introduction}

The land is an object that always be a struggle in the midst of society from the past until now, because of its special nature that is not owned by other production factors, not only have economic aspects but also political, legal and social aspects. ${ }^{1}$ The nature among others, the land can fulfill the basic needs and human permanent, the land quantity is limited and the land is fixed, ${ }^{2}$ in addition to economic value is also meaningful religio-cosmic and even ideological. ${ }^{3}$ A portrait of the land law in Indonesia long before the birth of the Basic Agrarian Law, that there was an organized trading agency in 1602 that sufficiently affected the history of agrarian law in Indonesia was the VOC (Verenicde OastIndische Compagnie) initially allowed the colonial regions to live by their custom, for his own interests cling to the teachings of his religion, that everything under the heavens is the interests of the King. After 1794 this trading agency broke out and the area was handed over to Bataafse Republiek who held the government in the homeland of Indonesia since 1800. In 1806 Bataafse Republiek turned into the Kingdom of the Netherlands and the power of colonial government than in the hands of the King of the Netherlands. ${ }^{4}$ The Netherlands is a colonial ruler who doubles as an entrepreneur. Colonial is characterized by 4 main characteristics, namely domination, exploitation, discrimination, and dependency. 5

The importance of land for the community is felt by the nation's fighters after the free Indonesian revolution that feels occupying the fertile but bounding equatorial region and does not feel the existence of independence in the ownership, control, let alone the management of land and land maximally because land policy after Indonesian independence is still feudal and capitalistic. One of the causes of the

\footnotetext{
${ }^{1}$ Y. Wartaya Winangun, SJ, Tanah Sumber Nilai Hidup, cetakan 1, (Yogyakarta: Kanisisus, 2004), p. 21.

2 I Way an Suandra, Hukum Perta na han Indonesia, (Jakarta: Rineka Cipta, 1994), p.v.

${ }^{3}$ Mustain, Petani VS Negara: Gerakan Sosial Petani Melawan Hegemoni Negara, (Yogyakarta: Ar-Ruzz Media, 2007), p.14.

${ }^{4}$ Rustandi Ardiwilaga, Hukum agrarian Indonesia, (Jakarta: Masa Baru, 1962), p.115

${ }^{5}$ Urip Santo so, Hukum Agraria \& Hak-Hak Atas Tanah, (Jakarta: Kencana Prenada Media Group), p. 28.
}

Faculty of Sharia and Law UIN Syarif Hidayatullah Jakarta - 235 


\section{Moh. Ali Wafa}

struggle for land reform through Law No. 5 of 1960 on Basic Agrarian Law (BAL) is the strengthening of the spirit of the nation's children at that time which is influenced by the dynamics of various ideologies and social-political forces contributing to anti-colonialism movement. ${ }^{6}$ One of the works of the nation's best, most monumental, and revolutionary child, namely Law No. 5 of 1960 on Basic Regulations of Agrarian Principles, hereinafter referred to as the Basic Agrarian Law (BAL) which first introduced the concept of the right to control the country. The historical record shows that the birth of BAL is a result of a feud of various interests in the old order. Land reform is an agrarian political strategy underpinned by the feud of some interests, especially the interests of farmers who do not have land against the interests of the landlords. ${ }^{7}$

Acknowledgment of land ownership which was realized with certificate since long time happened at Uthmanic Ottoman era as stated in Article 1737 Book of Civil Law. Similarly in other countries such as the UK, the certificate is an acknowledgment of the rights to a person's land as stipulated in the land registrations act 1925.

In Indonesia, the certificate of land rights serves as a strong evidence as defined in Article 19 paragraph (2) Sub-Paragraph c of the BAL and Article 32 paragraph (1) of Government Regulation Number 24 of 1997 concerning land registration, which now has been revoked and affirmed again in Government Regulation No. 24 of 1997. ${ }^{8}$

At the time of the President of the Republic of Indonesia (Soekarno) and Sadjarwo (Minister of Agrarian Affairs of the Republic of Indonesia) as two important figures in the formulation of the Basic Agrarian Law, In principle they are fighting for a law aimed at the distribution of large land in order to better level their control and

\footnotetext{
${ }^{6}$ Soetandyo Wignyosoebroto, Dari Hukum Kolonial Ke Hukum Nasional: dinamika Sosio Politik Perkembangan Hukum di Indonesia, (Jakarta: Rajawali Press, 1994), p.159

${ }^{7}$ Noer Fauzi, Petani dan Penguasa: Dinamika Perjalanan Politik Agra ria di Indonesia, Kerjasama Insist Press, KPA, (Yogyakarta: Pustaka Pelajar, 1999), p. 141.

${ }^{8}$ Pasal 31 dan Penjelasan Peraturan Pemerintah Nomor 24 Tahun 1997 tentang Pendaftaran Tanah (LN Tahun 1997 Nomor 59, TLN Nomor 3696). Adrian Sutedi, Setifikat Hak Atas Tanah, (Jakarta: Sinar Grafika, 2012), p. 1 236 - Jurnal Cita Hukum. Vol. 5 No. 2, December 2017. P-ISSN: 2356-1440. E-ISSN: 2502-230X
} 
ownership, ${ }^{9}$ in principle they fight aims to establish a broad division of land in order to better level its control and ownership. ${ }^{10}$

BAL tried to fight for the foundation of the principle of nationality that put the territory of Indonesia as a source of potential life endowed with God Almighty, the nation's fighters submit to the state to control not to have with the aim of reaching the maximum prosperity of the people to achieve a just and prosperous society, Article 2 Paragraphs (1), (2) and (3) of the BAL, are different from the principle adopted by Western law, is stated that the State owns the land as mentioned in the domain statement (Domeinverklaring). ${ }^{11}$

Likewise, the BAL also attempts to fight for customary law with the Principle of Recognition of Ulayat Rights ${ }^{12}$ as long as the ulayat rights still exist in reality and in accordance with national and state interests, the state recognizes such customary law as envisaged in Article 3 of the Basic Law of Social Function; serves not only the interests of the holder of the land, but is beneficial to the rightful owner and beneficial to the well-being and happiness of the nation and state, this principle can be observed from Article $6 \mathrm{BAL}^{13}$. The principle of nationality; Utilization of land for the nation, therefore not allowed land owned by foreigners as well as foreign legal entities. Only Indonesian citizens may own such land rights in Article 9 in conjunction with Article 21 paragraph (1). ${ }^{14}$ The principle of equality of rights; there is no discrimination between Indonesian men and women to acquire land rights and to obtain benefits and results. This principle is described in

\footnotetext{
${ }^{9}$ Noer Fauzi, Petani dan Penguasa: Dinamika Perjalanan Politik Agraria di Indonesia, Kerjasama Insist Press, KPA, (Yogyakarta: Pustaka Pelajar. 1999), p. 141

${ }^{10}$ Boedi harsono, Hukum Agraria Indonesia, Sejarah Pembentukan Undang-Undang Pokok a gra rian, Isi dan Pelaksanaannnya, Jilid 1 Hukum Tanah nasional, ( Jakarta: Djambatan, 2007), p. 5.

${ }^{11}$ Boedi harsono, Hukum Agraria Indonesia, Sejarah Pembentukan Undang-Undang Pokok Agrarian, Isi dan Pelaksanaannnya, Jilid 1 Hukum Tanah nasional, (Jakarta: Djambatan, 2007), p. 5.

12 Boedi Harsono, Hukum Agraria Indonesia: Sejarah Pembentukan Undang-Undang Pokok ag raria, Isi dan Pelaksanaanny a Jillid 1, (Jakarta: Djambatan, 2007), p. 185.

13 Boedi Harsono, Hukum Agraria Indonesia, Himpunan Peraturan-Peraturan Hukum Tanah, (Jakarta: Djambatan, 2006), p. 7.

${ }^{14}$ Boedi Harsono, Hukum Agraria Indonesia, Himpunan Peraturan-Peraturan Hukum Tanah, h.7.
} 


\section{Moh. Ali Wafa}

Article 9 paragraph (2). ${ }^{15}$ There are restrictions in the absence of control over the livelihoods and work of others beyond the limits, described in Article 11 paragraph (1), while in paragraph (3) it is stated that there is protection against the interests of the weak economic class. Then in Article 13 it is stated that monopolistic efforts in the agrarian field only can be done by the government and by law. The participants of the BAL also put the business principle actively by their owners; Farms should be done or cultivated by their own owners. For such purpose to be achieved, then as referred to in the provisions of Article 13 jo. Article 17 can be determined the minimum and maximum limits of land ownership / control of agricultural land, in the implementation can be revisited by Law no. 56 of $1960 .{ }^{16}$

Similarly, the principle of planning; everything that has a good and proper planning then certainly will succeed to the fullest. The management of the land required planning mainly to regulate the use, allocation and supply of earth, water and space for various life interests of the nation. With the hope of bringing abundant benefits to the people's welfare. It is thus mandated in Article 14 of the BAL. The management of the land towards economic improvement, the community has the authority or freedom to manage and enjoy a land location as an object. The term rights itself in Dutch is referred to as subjective retch, ${ }^{17}$ the authority gives pleasure and discretion to the individual who executes it, therefore Indonesia is referred to as a state of law, as matters relating to property rights have been regulated in accordance with existing provisions for the right Indonesian human rights can be maintained by embracing human rights as a citizen not as free as possible but still respecting the human rights of others. Therefore, Indonesian people not only have basic rights but also have basic

${ }^{15}$ Boedi Harsono, Hukum Agraria Indonesia, Himpunan Pera turan-Peraturan Hukum Tanah, p. 8 [Pasal 9 Article 2 :"Tiap-tiap warga negara Indonesia, baik laki-laki maupun wa nita mempunyai kesempa tan yang sama untuk memperoleh sesua tu hak atas ta nah untuk mendapat manfaat dan hasilnya, baik bagi diri sendiri maupun keluarganya "], in the same article.

${ }^{16}$ Boedi harsono, Hukum Agraria Indonesia, Himpunan Peraturan-Peraturan Hukum Tanah, p. 487.

${ }^{17}$ N.E.Algra.Dkk, Kamus Istilah Hukum, Penerjemah Saleh Adi Winata, (Jakarta: Bina Cipta, 1983), p. 443.

238 - Jurnal Cita Hukum. Vol. 5 No. 2, December 2017. P-ISSN: 2356-1440. E-ISSN: 2502-230X 
obligations. ${ }^{18}$ Will the objectives and targets of land law protect the economically weak group?. After seeing the development and influence and implementation of BAL which is no longer a legal umbrella for the rules and legislation related to ownership, and land tenure that can represent the main mission of the presence of BAL which is expected to be the eraser of colonial character characterized by the character of domination, exploitation, and discrimination. ${ }^{19}$ Strengthen the nationalism and put the territory of Indonesia as a potential source of life endowed with God Almighty. Continuing the struggle to resist the wickedness and humiliation of the people's seizure of land with the concept that the State owns the land as mentioned in the domains statement (Domeinverklaring). ${ }^{20}$ The Efforts to restore the mission of BAL with Islamic values which are very close to the content of customary law with the principle of recognition of Ulayat Rights, ${ }^{21}$ as long as the Ulayat right still exists in reality and in accordance with the national and state interests, the state recognizes the customary law as envisaged in Article 3 BAL. ${ }^{22}$ Placing the principles of property rights that can provide clarity of individual ownership respected, collective property, and state property mandated by the state to be managed responsibly.

The ownership of the land over the title certificate is proof of land rights. The strength of the enactment of the certificate has been affirmed in Article 19 paragraph (2) letter c and Article 32 paragraph (1) of Government Regulation Number 24 of 1997, namely the certificate is a proof of rights applicable as a strong evidence of physical data and juridical data contained in insofar as long as the physical data and juridical data in accordance with the data contained in the relevant land

\footnotetext{
${ }^{18}$ Sri Edi Swasono," Kompas, 14-08-2006).

${ }^{19}$ Urip Santoso, Hukum Agraria \& Hak-Hak Atas Tanah, (Jakarta: Kenc ana Prenada Media Group), p. 28

${ }^{20}$ Sunardi, Hukum Agraria, Badan Penerbit Iblam, p.16.

${ }^{21}$ Boedi Harsono, Hukum Agraria Indonesia: Sejarah Pembentukan Undang-Undang Pokok Agraria, Isi dan Pelaksanaanny a, p. 185.

${ }^{22}$ Urip Santoso, Hukum Agraria \& Hak-Hak Atas Tanah, (Jakarta: Kencana Prenada Media Group), p. 64
}

Faculty of Sharia and Law UIN Syarif Hidayatullah Jakarta - 239 


\section{Moh. Ali Wafa}

title and book. The land certificate proves that the right holder has a right to a certain plot of land. ${ }^{23}$

Similarly, how is the procedure of registration of land ownership for economically weak groups with a high cost so that they have no expense to register their land only they have land as a source of livelihood. So that the ownership of a person can be based on the law. ${ }^{24}$ Social function is utilized by recognizing the rights of others by respecting neighbors and their environment not only the interests of the holders of the land, but beneficial to the owners of rights and beneficial to the welfare and happiness of the nation and the State, the principle of the function of the land there are similarities in the picture of Article 6 BAL. ${ }^{25}$ Equal rights that do not recognize discrimination, but decisions based on deliberation. Land management must be undertaken or operated by the owner himself. For such purpose to be achieved, then as referred to in the provisions of Article 13 jo. Article 17 is determined the minimum and maximum limits of land ownership/control of agricultural land, in the implementation shall be revisited by Law no. 56 of $1960 .{ }^{26}$

The enforcement of BAL since its enactment in the 1960s from the end of the period has impeded implementation and is further away from the core of its original objective of improving the welfare of the weak economic class, the realization of freedom and legal certainty of land ownership, but what happens is increasingly pressing the weak and siding with the authorities. The phenomenon of society is increasingly confused in registering their land with expensive cost and also added with institution bureaucracy who is mandated between Land Deed Official, Notary, subdistrict and even urban village authorized to make land deed in sale and purchase transactions in a land transition process. The reality of implementation in the old order era is marked by

\footnotetext{
23 Adrian Sutedi, Setifikat Hak Atas Tanah, (Jakarta: Sinar Grafika, 2012), p.29.

${ }^{24}$ Abdullah, Dirâsatfial-Fikrial-Islamî, (Beirut Bayariq, 1990). 24

${ }^{25}$ Boedi harsono, Hukum Agraria Indonesia, Himpunan Peraturan-Pera turan Hukum Tanah, p. 7.

${ }^{26}$ Boedi harsono, Hukum Agraria Indonesia, Himpunan Pera turan-Pera turan Hukum Tanah, p. 487.

240 - Jurnal Cita Hukum. Vol. 5 No. 2, December 2017. P-ISSN: 2356-1440. E-ISSN: 2502-230X
} 
the land registration program based on the regulation number 10 of 1961. Then championed Law Number 2 of 1960. The Implementation of the legislation and government regulations mentioned above when experiencing severe obstacles because of the lack of support from both the people and farmers' organizations, the lack of conscious people to active register the land in the process of transitioning their land rights and they have not yet thought of the benefits and impacts of them. Political parties, figures and committees of land reform take unilateral action, either from hungry farmers or from the landlords. ${ }^{27}$ The soil redistribution program is also hampered by imperfect administrative flaws. The pros counter to the implementation of the revolutionary Laws and Regulations caused many actions so that Law No. 21 of 1964 on Landreform Court was issued.

Things that need to be considered, developed and implemented by the government given mandate is to build mentally the policy-holder, a land manager to animate and realize the implementation of natural resource exploration with two foundations, namely the foundation of creed and second is the moral foundation. A Muslim who must believe that an environment is a place not because it exists by itself, but it is because Allah's creation is granted to humans to be managed and maintained in their environment. From the foundation of the aqid appear the rules of Syari'ah which must be obeyed by every human being in interacting with its environment. Therefore the researcher hopes that the value of Islam of customary land is included as the main essences spirit to neutralize laws and regulations related to land in Indonesia, to maximize the ownership of the land that gets protection and legal certainty and they have registered the land can master and feel safe from disturbance of others, the regulation of land transition procedure which is simple to understand easily by the community and low cost to help the weak economic group so as to raise public awareness of the importance of land ownership gets protection and legal certainty that can minimize the occurrence of dispute in the middle of society that sustain the necessities of life.

${ }^{27}$ Noer Fauzi, Petani dan Penguasa: Dinamika Perjalanan Politik Agraria di Indonesia, (Yogyakarta: Kerjasama Insist Press, KPA, Pustaka Pelajar, 1999), p. 143-144

Faculty of Sharia and Law UIN Syarif Hidayatullah Jakarta - 241 


\section{The Function of Land Rights Certificate}

The final product of the land registration is a certificate of title to the land, has many functions for the owner, and its function cannot be replaced with other objects. First, the certificate of land rights serves as a powerful evidentiary tool. This is the most important function as mentioned in Article 19 paragraph (2) Sub-Paragraph c of the BLA. A person or legal entity will easily prove himself/herself as the holder of rights to a plot of land. If the name is clearly stated in the certificate. He can also prove the circumstances of his land, such as the area, its boundaries, the existing buildings, the type of rights and the burdens that exist on the land rights, and so on. All statements contained in the certificate have the force of law and should be accepted (by the judge) as true insofar as there is no other evidence to prove otherwise. If it turns out what is contained in it there is a mistake, then made changes and corrections as necessary. In this case, the right to hold the correction is not a court, but the National Land Agency as the agency that makes it. Persons who feel aggrieved due to errors in the certificate concerned, by attaching a Court Decision stating the existence of a mistake. ${ }^{28}$ Secondly, land title certificates provide trust to the bank/creditor to lend money to the owner. Thus, if the holder of land rights is a businessman for example, it would certainly make it easier for him to expand his business because of the need for capital easily obtained. Thirdly, for the government, the existence of land title certificates is also very profitable although the utility is mostly indirect. The existence of a land title certificate proves that the land in question has been registered with the Agrarian Office. The data on the relevant soil has been stored in the Land Office, and if at any time required is easily found. This data is very important for the planning of development activities such as urban development, installation of irrigation pipes, telephone cables, taxation of the earth and buildings and so on. ${ }^{29}$

\footnotetext{
28 Adrian Sutedi, Sertifikathak Atas tanah, p. 57.

${ }^{29}$ Sudjito, Prona Pensertifikatan Tanah Secara Massal dan Penyelesaian Sengketa Tanah yang Bersifat Strategis, Edisi Pertama, Cetakan Pertama, (Yogyakarta: Liberty, 1987), p. 72. 242 - Jurnal Cita Hukum. Vol. 5 No. 2, December 2017. P-ISSN: 2356-1440. E-ISSN: 2502-230X
} 


\section{The Land Certification through Prona}

Based on the Land Law Seminar in 1978 it was argued that obtaining certificates required a long time, and relatively high cost and no synchronization between government agencies concerned with land registration, and the existence of local regulations that deviated from the higher regulations. ${ }^{30}$ In addition to these factors, there are other nontechnical factors that are also underlying the birth, namely the attitude of agrarian agencies that are passive, waiting for the presence of community members (holders of land rights) who wish to register their land rights. In this way, the work becomes very slow. In addition, while the unscrupulous person who has a dishonest mentality, not helping the people (holders of land rights), but instead fooled him, which because of his behavior that arises a bad image of the agrarian institution. Secondly, the agrarian cycle at that time was less integrated, meaning that the tasks and functions of the situation with all its aspects were not running properly. Each function runs separately. ${ }^{31}$

\section{The Purpose of the Land Registration System with Program of Agrarian National (Prona)}

The objective to be achieved with Prona is to raise awareness of public law in the field of land as an effort to participate in creating political stability and economic development. So with this Prona the government provides incentives to holders of land rights in order to make certificates of ownership of their land and seeks to help to best resolve strategic land disputes by granting land holders various facilities, financing and acceleration of the certificate completion process. $^{32}$

Similarly, the purpose of Prona is to: 1) provide stimulation to the community, especially the holder of the right to land, to be willing to make a certificate, 2) to raise awareness of community law in the field of

${ }^{30}$ Lihat dalam buku Adrian Sutedi, Sertifikathak Atas Tanah, (Jakarta: Sinar Grafika, 2012), p. $65-66$.

\footnotetext{
31 Adrian Sutedi, Sertifikat Hak Atas Tanah, p. 65-66.

32 Adrian Sutedi, Sertifikat Hak Atas Tanah, p. 66-67..
}

Faculty of Sharia and Law UIN Syarif Hidayatullah Jakarta - 243 


\section{Moh. Ali Wafa}

land, 3) to assist the government in creating an atmosphere of community life safe and secure, 4) foster community participation, especially landowners in creating political stability and development in the economic field, 5) foster a sense of togetherness and assist the government in resolving land disputes, 6) providing legal certainty to holders of land rights, 7) familiarize the landowning community to have authentic proof of such right. ${ }^{33}$ Of the seven objectives of Prona, the most important objectives are: 1) conducting mass land certification programs throughout Indonesia, 2) thoroughly resolving strategic land disputes. ${ }^{34}$ In addition, Prona also aims to improve sporadic registration, especially to 1) make land registration systems more responsive to public demand (eg, by reducing shorter service times), 2) improve cadastral reliability (eg, by reducing false certificates through use of graphics index); 3) prepare a certain land office (eg. two in Sumatra) for systematic registration in the next phase. ${ }^{35}$

\section{The Impact of Negative Land Registry on Certificates}

Land registration according to Government Regulation No. 24 of 1997 using Negative Publication system. In this system the State passively accepts only what the requesting party declares. Therefore, at any time may be sued by people who feel more entitled to the land. Parties who obtain land from registered persons are not guaranteed. Although he obtained the land in good faith. It means that in the system of negative publication the statements contained therein shall have the force of law and shall be accepted as true information during and as long as there is no proving instrument proving otherwise. ${ }^{36}$

The advantages of the negative system are: a) the protection of the right holder; $b$ ) the presence of a land history investigation before

${ }^{33}$ Mudjiono, Politik dan Hukum Agraria, Cetakan Pertama, (Yogyakarta: Liberty, 1997), p. 85. Lihat dalam buku Adrian Sutedi, Sertifikat Hak Atas Tanah, (Jakarta: Sinar Grafika, 2012), p.. 96

${ }^{34}$ Adrian Sutedi, Sertifikat Hak Atas Tanah, p. 67-68.

${ }^{35}$ KPA, "Proyek Administrasi Pertanahan (PAP), Dalam buku Adrian Sutedi, Sertifikat hak Atastanah, p. 68.

244 - Jurnal Cita Hukum. Vol. 5 No. 2, December 2017. P-ISSN: 2356-1440. E-ISSN: 2502-230X 
the certificate is issued. ${ }^{37}$ In a negative registration system, for land registry officials there is no obligation to check on behalf of the registrant of their rights. Land registration officials register the rights in the general lists on behalf of the applicant without prior examination of the applicant, so that the registration work of transition of rights in the negative system can be done quickly and smoothly, as a result of no examination by the land registry officials. The weakness of the negative system is the unwarranted truth of the contents of the general lists provided in the course of land registration.

The negative system reflected in Article 19 of BAL, according to Boedi Harsono ${ }^{38}$ contains weakness, caused by a mistake when planning Article 23 paragraph (2) of BAL. Its history is in the draft UUPA proposed by the Minister of Agrarian Soenario contained in Article 19 said that the system of transfer of rights in the BAL when the birth of the owner's right is when the registration is done. Article 23 paragraph (2) of BAL is not only interpreted as a powerful evidence, but also as an absolute requirement of the birth of rights. This interpretation is in accordance with the words of the intent of Article 23 of the BAL and also the BAL systematics. When the birth of property for both parties and the third party is not placed on different momentum but at a moment, that is registrated. ${ }^{39}$.

The negative system has indeed created an impact on the legal certainty itself. Holders of land rights that can prove valid evidence will be protected by applicable law. The extent of the strength of proof of certificate, expressed as a powerful evidentiary tool by the BLA is provided on condition that as long as it has not been proven otherwise, the physical data and juridical data contained in the certificate must be accepted as true data, both in the daily legal proceedings and in the dispute as long as the data is in accordance with what is contained in the land records and books concerned, and the person can not claim the

${ }^{37}$ Adrian Sutedi, Sertifikat Hak Atas Tanah, p. 96

38 Bodi Harsono, Undang-Undang Pokok Agraria, Bagian Pertama, Jilid Kedua, (Jakarta: Djambatan, 1971), p. 57. Lihat dalam buku Adrian Sutedi, Sertifikat hak Atas tanah, (Jakarta: Sinar Grafika, 2012), p. 96

39 Adrian Sutedi, Sertifikat Hak Atas Tanah, (Jakarta: Sinar Grafika, 2012), p. 98.

Faculty of Sharia and Law UIN Syarif Hidayatullah Jakarta - 245 


\section{Moh. Ali Wafa}

land already certified on behalf of another person or legal entity, if for 5 (five) years from the issuance of the certificate the person who feels has the land not filed a lawsuit to the court, whereas such land is acquired by such person or other legal entity in good faith and is physically controlled by him or other person or by a legal entity that has his consent.

\section{Issuance of Certificates Due to the Transition of Legal Disability Rights}

Why are the protection and legal certainty of land ownership unfulfilled? And why are people still many and even reluctant to register their land to get a certificate? This is driven by several factors, ${ }^{40}$ including:

First is the historical factor of land ownership, second, psychological factors of society, third, weakness of land registration rules, fourth, implementation factors, and fourth, the law of Duties on Land and Building Transfer interventions and other costs. For this to be more obvious then described as follows: ${ }^{41}$

a. The historical factor of land ownership.

Obstacles to the State when the registration of land is still neglected and considered not to be important, so the current registration of the land is not considered a duty that can express the right to the land. Moreover, the ownership is a collective ownership, and then the proof of rights is not necessary, so that people are not secure to get the land. Land proof is always ignored, so interests do not materialize well.

b. Psychological factors of society

The public does not understand a significant difference between a certificate and no certificate of land. Even the protection granted by the State against the holder of the certificate is almost

${ }^{40}$ Adrian Sutedi, Sertifikat Hak Atas Tanah, p. 126

${ }^{41}$ Adrian Sutedi, Sertifikat Hak Atas Tanah, p. 115-116.

246 - Jurnal Cita Hukum. Vol. 5 No. 2, December 2017. P-ISSN: 2356-1440. E-ISSN: 2502-230X 
the same as that does not have a certificate. This lack of guarantees (tittle insurance) undermines the public's desire to register its land. People only want to register the land if there is a desire to use it, so the meaning of this certificate has not yet become vibrant from the protection of society.

c. The Weakness of land registration rules

Until now, many people are unaware of land registration rules. Therefore, it is materially expected to accelerate the registration of the land to be realized, but it is not, so there is no protection of the regulation, even the contents of the rule cannot be maintained to provide a tool for the achievement of the targets of land rights certificates in Indonesia.

d. Implementation factors

There are still many public complaints on the implementation of land registration. As a result implementation is sometimes considered not assertive and even different interpretations in doing his job. If this arises, it will certainly not be encouraged the community to register the land.

e. Intervention of the Duties on Land and Building Transfer

Act and other costs in the case of wishing to register the land at present, in addition to meet applicant fees stipulated by land registration rules, there are still other costs of non-negligible legislation, such as Law Number 21 of 2001 on Duties on Land and Building Transfer, other UN legislation. All fees charged from the provisions of the land registration rules themselves make people reluctant to register their land, especially in rural areas.

This indicator becomes a problematic implementation of land registration, so the implementation of land registration does not realize legal certainty. Even these factors lead to the emergence of land registration issues, namely false certificates, asphalt certificates, double certificates, and blocking of certificates by banks. 
Legal uncertainty for community land should be a concern for the government to immediately socialize what and how the registration of land and the purpose of registration. If left unchecked will encourage the public's uncertainty over the proof of the right itself because it is deemed unable to protect the land rights of the people. If the land certificate is still deemed only to be used for a particular purpose only so that the people of ignorance over the registration of land in this Country. ${ }^{42}$

\section{Issuance of Certificates Based on Right Base under Hands}

Issuance of Certificates Based on Right Base under Hand. ${ }^{43}$ The enormous number of registrants in land registration using the title of the right in the form of adeed under the hand greatly affects the state of society, where there is still a lot of lands that has not been certified. This is of course caused by the mechanism of registration of land is too heavy for the community both procedures and registration fees. ${ }^{44}$

Land registration is essentially aimed at ensuring the right of the landowner. The issuance of a certificate is a safeguard to the landowners of their rights to the land. In order to provide legal certainty to the holders of land rights, the certificate of land serves as a strong proof. A land certificate is a valid proof as a strong proof of the physical data and juridical data contained therein, as long as the data is in accordance with the data contained in the relevant land meters and books. ${ }^{45}$

One of the problems that are closely related to legal certainty in land registration is the problem of proof. In the registration of land known 2 (two) registration of rights, ${ }^{46}$ namely the right to new land and the old land rights, and for more details will be described as follows:

\section{The right to new land}

${ }^{42}$ Adrian sutedi, Sertifikat Hak Atas Tanah, p. 226-228

${ }^{43}$ Adrian Sutedi, Sertifikat Hak Atas Tanah, p. 45

${ }^{44}$ Adrian Sutedi, Sertifikat Hak Atas Tanah, p. 177-178.

${ }^{45}$ Adrian Sutedi, Sertifikat Hak Atas Tanah, p. 176.

${ }^{46}$ Adrian Sutedi, Sertifikat Hak Atas Tanah, p. 176

248 - Jurnal Cita Hukum. Vol. 5 No. 2, December 2017. P-ISSN: 2356-1440. E-ISSN: 2502-230X 
a. New land titles are validated by:

1) Determination of the granting of rights of the competent authority to grant the rights in accordance with the provisions applicable if the granting of rights derived from the State land or the land of the original management rights of the PPAT deed containing the granting of rights by the holder of the right to the beneficiary concerned for the right to use the building and the right to use over land property rights. Management rights are evidenced by the determination of granting of rights by authorized officials.

2) Wakaf land proven by the deed of pledge of waqf;

3) Property right of apartment units as evidenced by the deed of separation;

4) Provision of Deposit Rights is evidenced by the deed of granting of the Deposit Rights. ${ }^{47}$

b. Proof of old rights under Article 24 PP. 24 of 1997, namely:

For the purposes of land registration, land rights arising from the conversion of old rights are evidenced by evidence of the existence of such right in the form of written evidence, statements of witnesses or statements in question which are of sufficient truth to register the rights, rights holders and others burden him.

In the case of no or no longer fully available the evidence, the proof can be made based on the physical arrangement of the land for 20 years or successively by the applicant of the registration and its predecessors. ${ }^{48}$

\section{The old right.}

In article 60 of PP. 24 of 1997 there is some written evidence that can be used for registration of old rights is a complete document for the

\footnotetext{
${ }^{47}$ Adrian Sutedi, Sertifikat Hak Atas Tanah, p. 176.

${ }^{48}$ Adrian Sutedi, Sertifikat Hak Atas Tanah, p. 177.
}

Faculty of Sharia and Law UIN Syarif Hidayatullah Jakarta - 249 


\section{Moh. Ali Wafa}

purposes of land registration is grosse deed of eigendom right, certificate of ownership issued based on the rules of the autonomous government concerned, certificate of property issued based on Ministerial Regulation no. 9 of 1959, decree on the granting of property rights from authorized officials either before or since the entry into force of BAL, pet tax before the entry into force of PP. 10 of 1961, the deed of transfer of rights made under the hands of a testimony by the Chief Customary / Village Heads made before the enactment of PP. 24 of 1997 with transfer of rights transferred, deed of transfer of rights made by Official Certifier of Title Deeds (PPAT), deed of pledge of waqf, auction paper made by Official Auction, letter of appointment or purchase of land taken by the government, a certificate of land history made by the Tax Office Earth and Building with accompanying rights transferred. ${ }^{49}$

\section{Conclusion}

From the description of the issuance of certificates mentioned above can be concluded there are several factors causing land dispute in the middle of society are as follows:

1) Issuance of a land certificate with negative publication system does not provide legal certainty to the person registered as the right holder because the State does not guarantee the truth of the data presented.

2) In Article 23, Article 32, and Article 38 of the Law on the Law states that "Registration is a powerful evidentiary instrument." And it has been explained that the government adopts a negative system means that the certificate is not protected as a legal holder. Issuance of certificates means the issuance of rights is not absolute. Conversely, if there is legal protection for the holder of the certificate cannot be contested.

3) The disadvantage of this Negative System is that it will open the possibility to anyone who feels entitled to the land to file a

${ }^{49}$ Adrian Sutedi, Sertifikat Hak Atas Tanah, p. 177.

250 - Jurnal Cita Hukum. Vol. 5 No. 2, December 2017. P-ISSN: 2356-1440. E-ISSN: 2502-230X 
lawsuit to the District Court or TUN Court even if on the disputed land it has been issued a certificate.

4) The weakness of the negative publication system is that the party whose name is listed as the right holder in the land and certificate books always faces the possibility of a lawsuit from another party who feels the possession of the land.

5) The impact of a negative publication system on certificates, many lawsuits or land cases that arise because they cannot be resolved by the parties to the dispute so that it must be examined and decided by the court.

\section{Bibliography}

Ardiwilaga, Rustandi. Hukum agrarian Indonesia, (Jakarta: Masa Baru, 1962).

Fauzi, Noer. Petani dan Penguasa: Dinamika Perjalanan Politik Agraria di Indonesia, Kerjasama Insist Press, KPA, (Yogyakarta: Pustaka Pelajar, 1999).

Harsono, Budi. Undang-Undang Pokok Agraria, Bagian Pertama, Jilid Kedua, (Jakarta: Djambatan, 1971).

Mustain. Petani VS Negara: Gerakan Sosial Petani Melawan Hegemoni Negara, (Yogyakarta: Ar-Ruzz Media, 2007).

Pertama, (Yogyakarta: Liberty, 1987).

Santoso, Urip. Hukum Agraria \& Hak-Hak Atas Tanah, (Jakarta: Kencana Prenada Media Group).

Suandra, I Wayan. Hukum Pertanahan Indonesia, (Jakarta: Rineka Cipta, 1994).

Sudjito. Prona Pensertifikatan Tanah Secara Massal dan Penyelesaian Sengketa Tanah yang Bersifat Strategis, Edisi Pertama, Cetakan

Sunardi. Hukum Agraria, (Jakarta: Iblam, 2005).

Sutedi, Adrian. Setifikat Hak Atas Tanah, (Jakarta: Sinar Grafika, 2012). 


\section{Moh. Ali Wafa}

Wignyosoebroto, Soetandyo. Dari Hukum Kolonial Ke Hukum Nasional: dinamika Sosio Politik Perkembangan Hukum di Indonesia, (Jakarta: Rajawali Press, 1994).

Winangun, Y. Wartaya SJ. Tanah Sumber Nilai Hidup, cetakan 1, (Yogyakarta: Kanisisus, 2004).

Yunus, Nur Rohim, Restorasi Budaya Hukum Masyarakat Indonesia, Bogor: Jurisprudence Press, 2012. 